\title{
Why the eversion of the endophallus of honey bee drone stops at the partly everted stage and significance of this*
}

\author{
Jerzy WoYKE \\ Apiculture Division, Agricultural University, 166 Nowoursynowska, 02-787 Warsaw, Poland
}

Received 21 April 2008 - Revised 19 June 2008 - Accepted 24 June 2008

\begin{abstract}
After the drones are excited, they evert the endophallus, which mostly stops at partly everted stage with a slender tip at the end. The reason of the stop and the appearance of the tip is not known. There are transversal hairy folds at the ventral border of the cervix of honeybee drone endophallus. They form a duct inside the cervix. The dorsal walls of the duct come together at an acute angle and join at the summit quite tight. During partial eversion, the cervical duct appears at the end; however, its dorsal walls do not open (separate). The diameter of the duct is $0.4-0.5 \mathrm{~mm}$. The bulb of the endophallus is not able to pass through such a small duct and therefore the eversion stops. Only after the pressure inside partly everted endophallus is increased sufficiently, the dorsal walls of the duct are opened, the interior of the cervix is enlarged and the bulb passes through it, which results in full eversion. The increased pressure inside the endophallus results in the semen being ejected with greater force. This is important during multiple matings of queen bees.
\end{abstract}

eversion / endophallus / Apis mellifera / reproductive organs / drone

\section{INTRODUCTION}

The drones of all Apis species have unique copulatory apparatus. It consists of large complicated tube, the so called endophallus, inside the abdomen. To ejaculate the semen, the drone everts the endophallus outside the tip of the abdomen.

Already 270 years ago, Swammerdam (1738) had presented quite good drawings of the uneverted (his Tab. XXI) and everted (Tab. XXII) drone endophallus.

Later, many papers were published, which presented and described uneverted and everted endophallus and the process of eversion. Included in these later publications were Huber (1792), Leuckart (1873), Wolf (1876), Michaelis (1900), Bishop (1920), Zander (1922), Arnhart (1936 and 1937), Laidlaw

Corresponding author: J. Woyke, jerzy_woyke@sggw.pl

* Manuscript editor: Stan Schneider
(1944), Fyg (1952), Snodgrass (1956), Woyke (1958a) Ruttner (1968) and others.

The process of eversion was illustrated by Woyke (1955 and 1958b) and by Woyke and Ruttner (1958). The most detailed description of the eversion of the endophallus was presented by Woyke (1958b). Unfortunately, except for the abstract written in English, the main text was written in Polish and several important findings are not well known. The creation of the mating sign, without damaging the everted endophallus was described by Woyke (1958b) and Woyke and Ruttner (1958).

The basic findings concerning the structure of the endophallus and the process of eversion, necessary to understand the new findings, are as follows: An uneverted endophallus, as it looks in the abdomen of A. mellifera drones, is presented in Figure 2 (dorsal view) and in Figure 3 (ventral view) The different parts are better visible when the endophallus is extended (Fig. 4 lateral view and Fig. 5 ventral view). The endophallus is composed of three main 


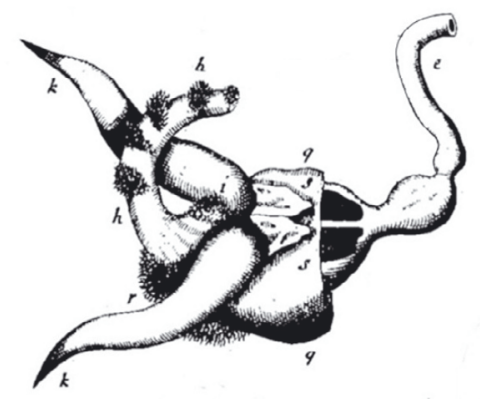

Figure 1. Swammerdam, 1738, partly everted endophallus, $\mathrm{h}$ - slender tip at the end.

parts: the bulb, the cervix and the vestibulum (Figs. 4 and 6). The bulb is provided with the chitinous plates (Figs. 2 and 3 ). The cervix has the fimbriate lobe at one side and the transversal folds at the other side (Fig. 8). The vestibulum has two yellow cornua (Fig. 4). Inside the abdomen, the chitinous plates of the bulb and the fimbriate lobe lay at the left side of the abdomen. However, during eversion, they turn to the dorsal side (Fig. 23). Therefore, the side of the endophallus with the chitinous plates and the fimbriate lobe is called dorsal. The opposite with the transversal folds is called ventral side. The endophallus has no any muscles.

When the drones are excited and their thorax is squeezed, abdominal muscles contract and the pressure of the hemolymph inside the abdomen increases considerably. As a result, the endophallus is pushed out of the abdomen being everted. The drone dies during this process. Mostly two stages of eversion occur. At first, the endophallus is everted only partly (Fig. 17) and afterwards full eversion occurs (Fig. 26). The partly eversion of the endophallus stops with a slender tip at the end (Fig. 17).

Already Swammerdam (1738) demonstrated a slender tip with hairy transverse folds at the end of the partly everted endophallus (Fig. 1). However, during 270 years, no explanation was ever given as to why the endophallus of all excited drones do not evert fully, but mostly stops at the partly everted stage and why the slender tip appears at the end of partly everted endophallus.
Koeniger (1984) allowed free flying drones to mate with queens whose sting chambers were held open with glue. In most cases, the eversion of the endophallus stopped at partly everted stage. Thus, during natural mating, partial eversion of the endophallus also occurs. This stage must play an important role in the natural mating of honey bees.

The partly everted endophallus play an important role in instrumental insemination of queen bees. The easiest way to collect the semen is from the end of the everted endophallus just after the stage of partial eversion (Fig. 23). Every year, about 100000 honeybee queens are instrumentally inseminated worldwide. To inseminate those queens, the semen is collected from about 800000 drones. To collect the necessary amount of semen more than 1 million endophalli must be everted. Despite the enormous high number of eversions and observations, nobody explained, why partly eversion of endophallus with a slender tips at the end occurs?

Therefore, I investigated the structure of the endophallus and the process of eversion. I tried to explain why the eversion of the endophallus stops at the partly everted stage and why a slender tip occurs at the end when no any baffle of the endophallus exists.

\section{MATERIALS AND METHODS}

Drones, which were at least several days old (dark hairs) were collected from the hive. They were then chilled in a refrigerator $\left(4^{\circ} \mathrm{C}\right)$ for several minutes, until they were motionless. The purpose was to decrease the response of the nervous system and also to decrease the response of the muscle for manipulation during dissecting. The drones were sectioned in Petri dishes filled either with physiological solution $(1 \% \mathrm{NaCl})$ or with $45 \%$ alcohol. After a drone was fixed to the wax bottom, a quick cut was made between the 1st and 2nd abdominal sclerite. Immediately the abdomen was opened slightly and the ductus ejaculatorius was cut off to prevent filling the endophallus with semen from seminal vesicles and with mucus from mucus glands. Afterwards, the endophallus was taken out of the abdomen. The endophallus was stretched out and pinned with entomological needles to the bottom. This enabled a better investigation of different parts 
of the endophallus. Sometimes cross sections were made with small scissors. Before this, the endophallus had been fixed with alcohol. The partly everted endophallus was also sectioned in a similar way.

To study the process of eversion, drones, which had not been chilled, were used. They were excited by holding them by one of their legs near light and allowing them to try to fly. Afterward, the thorax was squeezed, which resulted in partial or full eversion of the endophallus. To get the intermediate stages, the abdomen of the drones with a partly everted endophallus was gently squeezed until the required stage of eversion occurred.

The endophallus or its parts were photographed with a digital camera.

\section{RESULTS}

\subsection{Structure of uneverted endophallus}

The endophallus behind the bulb does not present a large tube, but is flattened and folded. The part behind the bulb is called the pocket (Fig. 6). Two large folds are folded beneath the chitinous lateral plates at both sides of the bulbus. These are the longitudinal folds which connect the bulb with the cervix (Fig. 6, longitudinal fold). A small flat canal connecting the bulb with the posterior parts of the endophallus is present at the interior dorsal part of the pocket (Fig. 6, canal). A flattened pouch is located at the posterior half of the pocket, between the two longitudinal folds (Fig. 6 pouch). The pouch is opened dorsally, and it is virtually an invigilation of the ventral wall of the pocket. The inside walls of the pocket and the nearby areas of the folds are covered with numerous tiny spines (Fig. 7). The posterior part of the pouch is closed because its walls are stuck together by hairy edges. The part behind the pouch, up to the vestibulum at the rear, is the cervix (Fig. 6, cervix). The cervix is a flattened tube whose inside walls touch each other. However, unlike the pouch, the inside walls of the cervix are smooth without any spines or hairs.

At the ventral wall of the cervix, a structure is present called differently by different authors and in this paper is called transversal folds (Fig. 8) following Woyke (1958a). Up to
12 such folds can be observed. Increased magnification of the picture showed, that the structure presents a duct at the ventral border of the cervix (Fig. 9).

The cross section through the duct showed, that it has the shape of a section of falling drop, and the dorsal walls come together at an acute angle, at the point of which they are tightly pressed together (Fig. 10), (something like a Gothic ceiling). The dorsal slops of the ceilings are joined together at the summit. The inside walls of the duct are covered with hairy fields and folds.

The duct stretches from the pouch at the front, along the whole cervix up to the vestibulum at the rear. It is possible to insert a needle, with a diameter of $0.3 \mathrm{~mm}$, through the vestibulum into the whole duct, up to the pouch (Fig. 11). However, when a larger needle, with a diameter of $0.5 \mathrm{~mm}$ is inserted, it is possible to insert it only partly (Fig. 12). This mean, that the anterior (cranial) end of the tube is narrower than the posterior (caudal). It is easily to split the dorsal, posterior part of the duct up to the length opposite the II ventral hairy field (Fig. 12). However, it is more difficult to go up much further cranially, up to beyond the part where the tip of the $0.5 \mathrm{~mm}$ needle penetrated.

Much force is needed to split the dorsal cranial part of the duct. After the dorsal wall of the whole duct is split and the walls are flattened, the view, presented in Figure 13 appears. Only 4 (sometimes 5) Vshaped hairy fields are present on the ventral side of the duct, (which is also the ventral side of the cervix). The two V-shaped fields near the shield of vestibulum (I and II) are more obtuse and the two other (III and IV) more conical. The two middle fields (II and III) are larger than the two outsides (I and IV). Sometimes a small additional ventral hairy field (0) is present between field I and the shield of the vestibulum. The V-shaped hairy fields at the ventrum of the duct present a kind of spreaders. These spreaders prevent adhesion of the lateral walls.

Enlargement shows that the 12 hairy folds are not present on the ventral wall of the duct, but only on the side-dorsal parts of the duct (Fig. 14). 


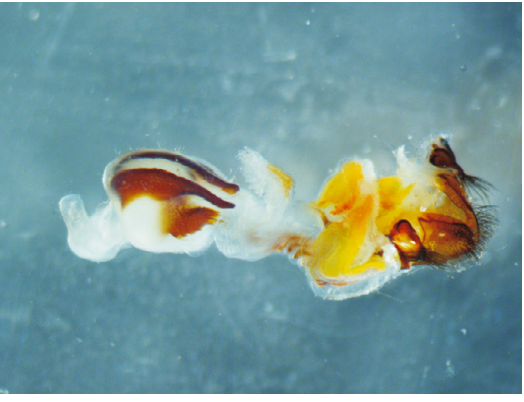

Figure 2. Drone endophallus, dorsal view.

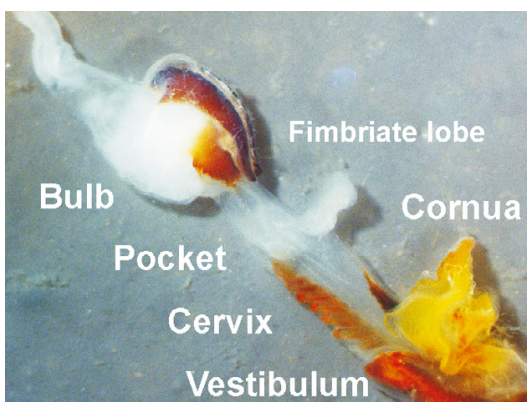

Figure 4. Stretched endophallus, lateral view.

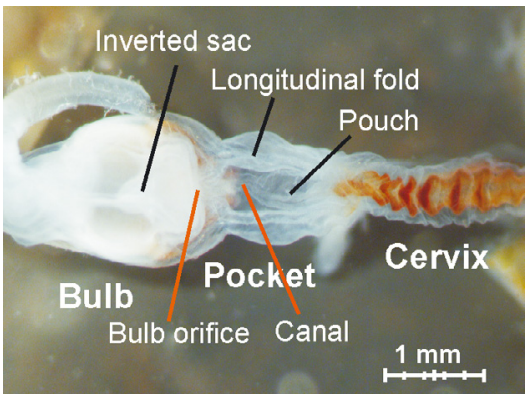

Figure 6. Endophallus, ventral view.

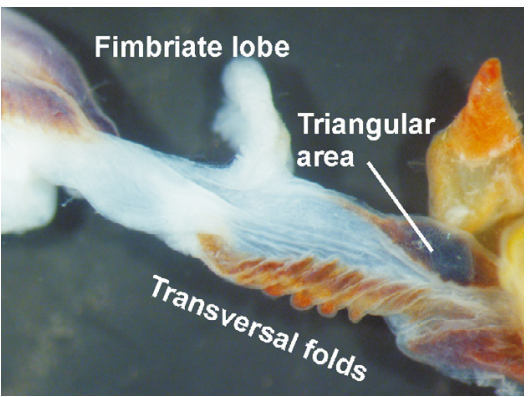

Figure 8. Transversal folds, lateral view.

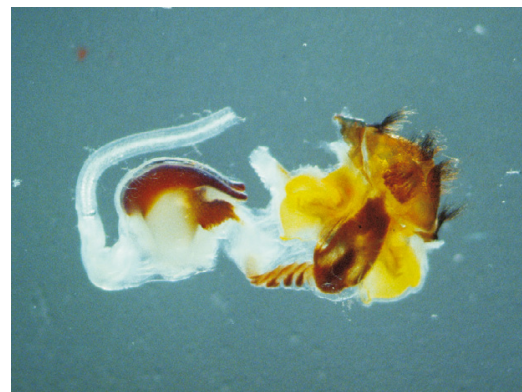

Figure 3. Drone endophallus, ventral view.

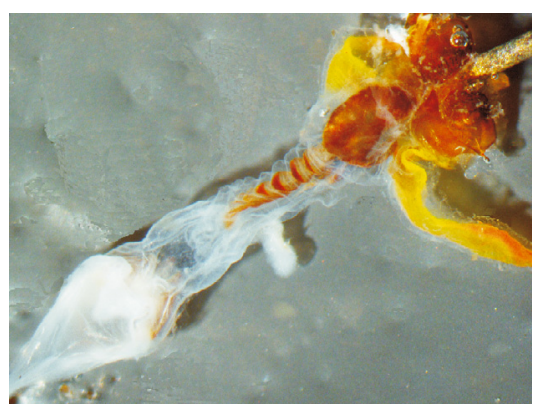

Figure 5. Stretched endophallus, ventr. view.

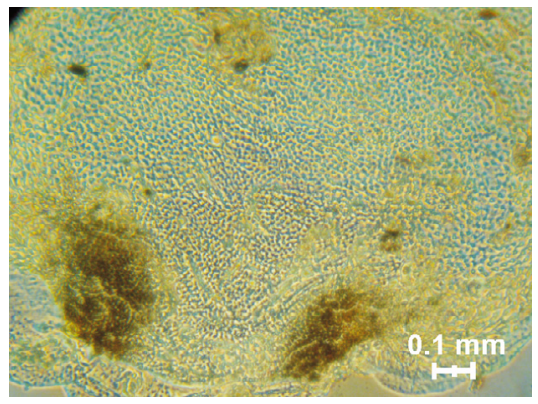

Figure 7. Pouch wall with spines.

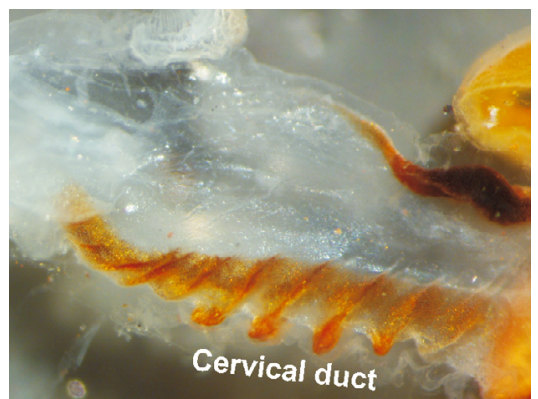

Figure 9. Cervical duct. 
Two longitudinal hairy bands are present along both dorsal edges of the slopes of the acute angle ceiling of the duct (Fig. 13). The bands extend from the pouch at the front, pass longwise along the inner dorsal walls of the duct, up to the shield of vestibulum at the rear.

Large hairy thorns cover the ventral Vshaped fields as well as the longitudinal hairy bands (Fig. 14). Inside the cervix, the outside edges of the longitudinal hairy bands are bended up, and they join together creating the acute angle ceiling of the duct (Fig. 10). The slops of the ceiling adjoin on at varying widths. At the rear, near the vestibulum, only the edges of longitudinal hairy bands join together. However, further cranially, starting opposite the III ventral V-shaped area, the hairy slopes of the acute angle ceiling adjoin on a larger width. Near the pouch, they adjoin almost on their whole width (Fig. 15). A ventricle view shows the ajoining dorsal wall as a line in the middle of the duct (Fig. 16). The junction of the dorsal sidewalls of the duct makes it difficult to separate them.

\subsection{Eversion of the endophallus}

After the drones are excited, and their thoraxes are squeezed, partly eversion of endophallus (Fig. 17) occurs in most drones. At first, the vestibulum and the cornua are everted. The empty bulb of the endophallus is pushed inside the everted vestibulum. Then, the bulb is filled with semen and mucus.

The partly eversion of the endophallus stops with the slender cervical duct at the end. The four (to five) V-shaped hairy fields are visible at the ventral side of the duct (Fig. 18).

The duct appeared at the end of the partly everted endophallus, because its dorsal wall did not open. Figure 18 shows that the summit edges of the slopes of the acute angle ceiling of the duct, are separated only opposite transversal fields I and II. This is similar to what happened with the introduction of a needle of $0.5 \mathrm{~mm}$ diameter into the duct of an uneverted endophallus (Fig. 12). In the partly everted endophallus, the dorsal longitudinal hairy bands of the duct are visible at both sides of the slender tip of the endophallus (Fig. 18). However, the ceiling of the duct is not opened opposite the transversal fields III, IV and V, (Fig. 18) and the longitudinal hairy bands are inverted inside the dorsal wall of the cervical duct. As a result, a slender duct of $0.4-0.5 \mathrm{~mm}$ diameter appears at the end of the partly everted endophallus.

Inside the everted part of the endophallus is the bulb, filled with mucus (Fig. 19), whose diameter is about $2 \mathrm{~mm}$. Thus, the bulb is not able to pass through the slender duct. As a result, the eversion of the endophallus stops at the partly everted stage, with the slender duct at the end.

To perform further eversion of the endophallus, considerable increase of the pressure inside the everted part is indispensable. After the required level of pressure is reached (artificially or naturally), the dorsal wall of the cervical duct is opened in a peculiar way. At first, the pouch is pressed through the duct. As a result, a transparent vesicle appears at the end of the endophallus (Fig. 20). More pressure enlarges the vesicle. This cause opening of the dorsal wall of the duct starting from the posterior end (Fig. 21). Increasing the pressure enlarges the vesicle and opens the duct more cranially. A dorsal view shows that not only the pouch is pushed through the duct, but also part of the lateral folds (Fig. 22). The walls of the pouch and of the lateral longitudinal folds are covered with many small spines (Fig. 7). This additionally makes it more difficult to pass these parts through the cervical duct and thus to open the dorsal wall of the slender tip.

After the dorsal wall of the duct is opened, the whole interior of the cervix is unified and enlarged. Now, the bulb with the chitinous plates is pushed into the cervix and farther on, into the pocket of the longitudinal folds. The orifice to the bulb is now at the end of the so far everted endophallus. As a result, the semen is now ejaculated (Fig. 23). The semen is now at the end of the endophallus. This is the best stage of eversion to collect the semen without mucus, for instrumental insemination.

This is also probably the stage at which, the semen is injected during natural mating; into the oviducts of the queen. 

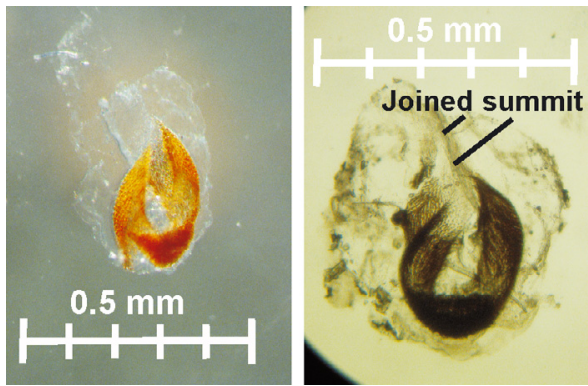

Figure 10. Cross section through cervical duct. Left stereo microscope, right optical microscope.

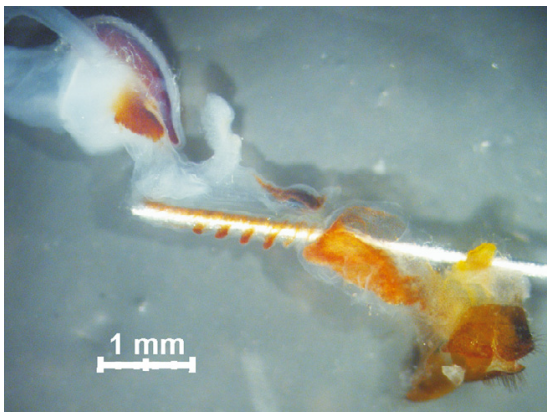

Figure 11. Needle $0.3 \mathrm{~mm}$ inside cervical duct.

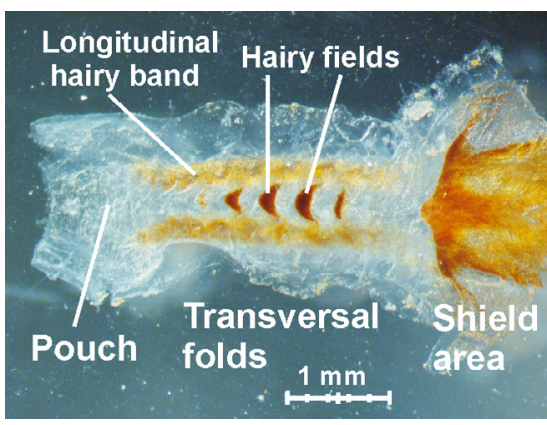

Figure 13. Cervical duct opened and flattened.

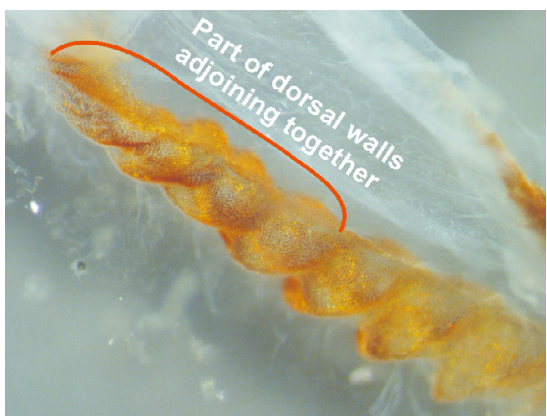

Figure 15. Cervical duct, lateral view.

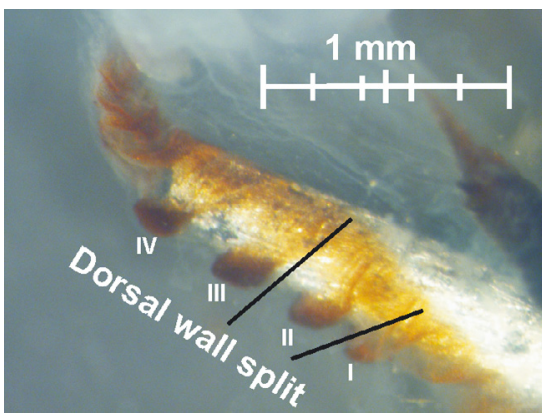

Figure 12. Needle $0.5 \mathrm{~mm}$ inside cervical duct.

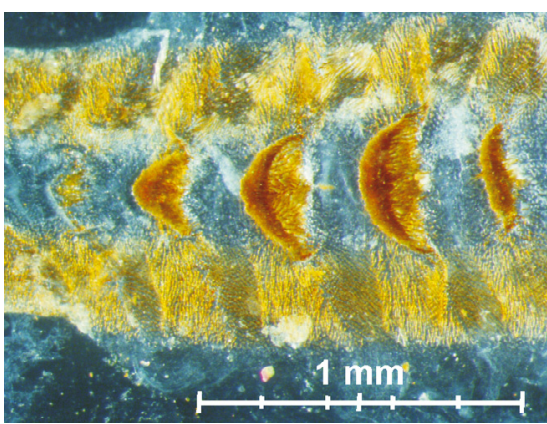

Figure 14. Hairy thorns at inside wall of cervical duct.

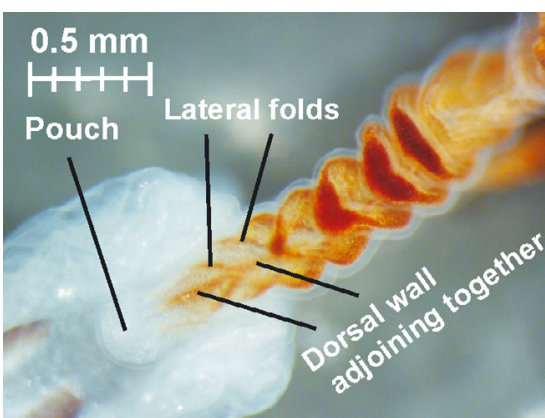

Figure 16. Cervical duct, ventral view. 
When the bulb passes through the cervix, it enlarges the interior of the cervix so much, that the lateral hairy bands (now outside everted endophallus) are disrupted along their length (Fig. 24).

The end result is a fully everted endophallus (Fig. 25). The chitinous plates of the bulb are now everted. When the full eversion of the endophallus was induced by a slow gradual increase of pressure, the picture visible in the last figure occurs. The semen is located near the chitinous plates of the bulb. The mucus covers the dorsal wall and the end of the endophallus. However, when full eversion of the endophallus resulted spontaneously, as a result of large increased pressure inside the endophallus, the semen is ejected with great force directly from the end of the endophallus. Then the semen is not between the chitinous plates of the bulb but at the end of the everted endophallus and even at the thorax of the drone (Fig. 26).

\section{DISCUSSION}

Swammerdam (1738) presented quite good drawing of partly everted drone endophallus (Pl. XXII, Fig. 1), already 270 years ago. Since that time, many papers have shown and described the partly and fully everted endophallus as well as the process of the eversion of the endophallus of $A$. mellifera drones.

All the descriptions and figures show the partly everted endophallus with a slender tip at the end and the 4-5 hairy transversal fields.

It is important to note that in those papers no explanation was ever given as to why the endophallus does not evert fully at once. Why a slender tip appears at the end of partly everted endophallus? Such questions like the following ones were not answered. Why does the cervix not evert after the vestibulum everted? Why is only part of the cervical duct everted? The role of the cervical duct in the eversion of the endophallus was not described. Why does the cervical duct at the end of a partly everted endophallus stop the full eversion of the endophallus?

I showed that a duct is present inside the ventral border of the uneverted cervix. The dorsal walls come together at an acute angel, at the point of which they are tightly pressed together.

After partial eversion, the slender tip visible at the end of the partly everted endophallus is created by the uneverted cervical duct whose dorsal wall did not open. The bulbs can not pass trough such slender duct and as a result, the eversion of the endophallus stops.

My and all earlier descriptions indicate, that the endophallus everted only partly because the pressure inside the everted part of the endophallus was to weak to force opening the dorsal wall (to separate the slops) of the slender cervical duct at the end of the endophallus.

Considerable increase of the pressure inside the everted part of the endophallus is required, to provoke further eversion. The pressure can be increased artificially by squeezing the abdomen of the drone. It occurs also naturally in very excited drones.

Further eversion of the endophallus can be continued only after the dorsal wall of the cervical duct is opened. Until now nobody even mentioned, how the slender cervical duct at the end of the partly everted endophallus is opened. I showed that this occurs in a peculiar way starting from the posterior to the anterior direction. After the dorsal wall of the slender tip is opened, the whole interior of the cervix is united and enlarged. Now the bulb pass trough it and the semen is ejaculated.

When the bulb passes through the cervix, it enlarges the interior of the cervix so much, that the lateral hairy bands (now outside everted endophallus) are disrupted along their length. Wolf (1876) presented those bands on everted endophallus already 132 years ago. However, despite many publications, no explanation was ever given about their role. I showed, that the hairy bands join the inside dorsal walls of the cervical duct so tight, that the initial pressure inside the everting endophallus is too weak to separate them. As a result the eversion stops. Considerable increase of the pressure inside partly everted endophallus is required to provoke full eversion. Thus, really the tightly joined dorsal borders of the longitudinal hairy bands prevent the eversion of the cervical duct. As a result, the slender tip is created at the end of the endophallus and this stops the eversion at the partly everted stage. 


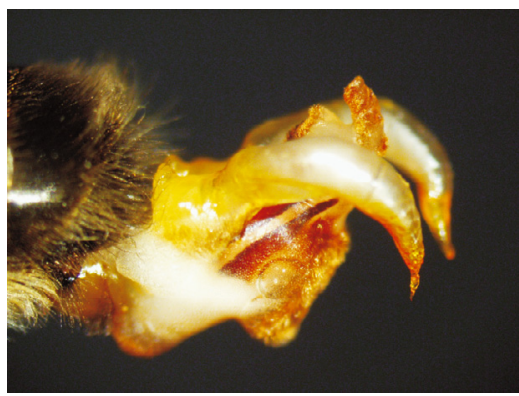

Figure 17. Partly everted endophallus.

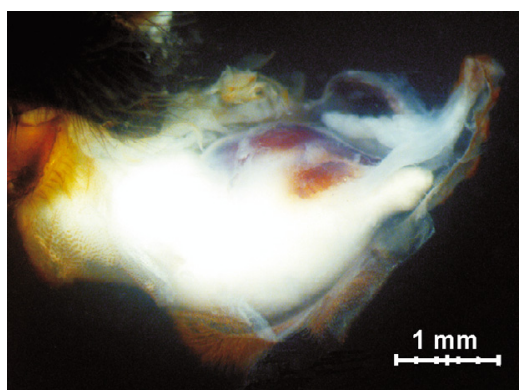

Figure 19. Partly everted endophallus, the outside wall removed.

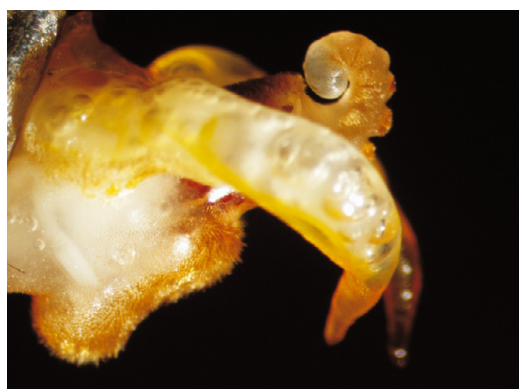

Figure 21. Enlarged pouch opens the duct starting from the distal end.

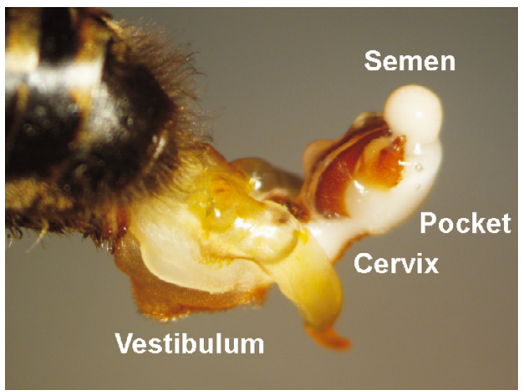

Figure 23. Semen at the end of everted endophallus.

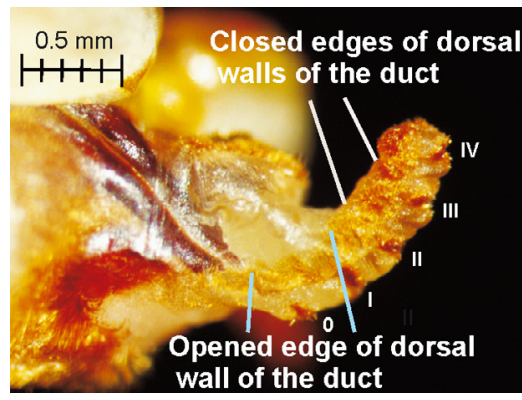

Figure 18. Cervical duct at the end of partly everted endophallus.

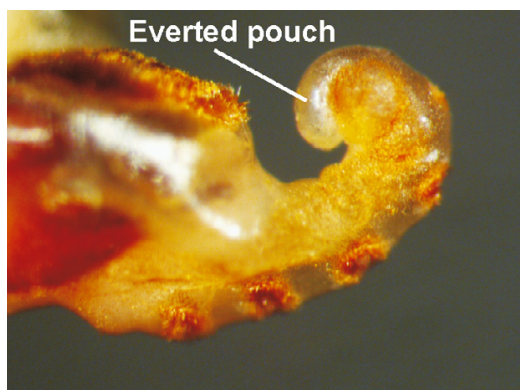

Figure 20. Cervical duct with everted pouch at the end.

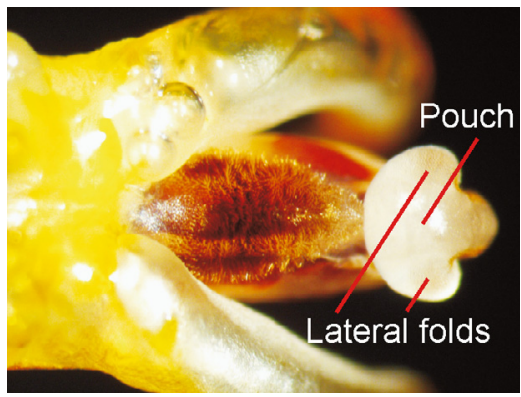

Figure 22. Everted pouch and part of the lateral folds at the end of the endophallus, dorsal view.

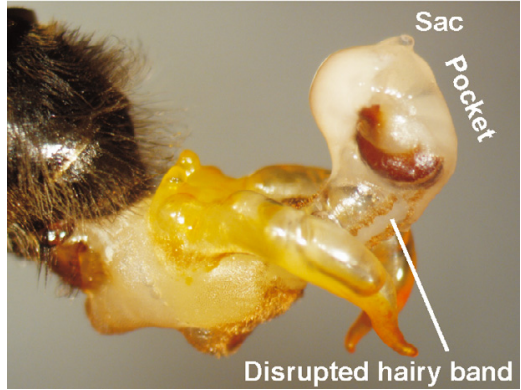

Figure 24. The bulb in the pocket of everted endophallus. 


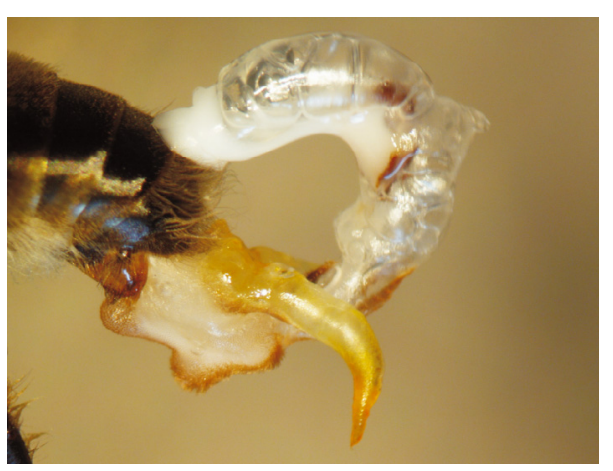

Figure 25. Fully everted endophallus, semen near chitinous plates.

The ejection of semen under increased pressure is much faster (stronger), than when ejected under the initial weak pressure inside a partly everted endophallus.

The ejection of semen under great force is very important during natural mating. The mating of honey bees occurs in open air, where the queen is mated by several drones during one mating flight (Woyke, 1955). During natural mating, the slender duct at the end of a partly everted endophallus penetrates into the vaginal orifice of the queen. The increased pressure inside the endophallus, injects the semen with great force. The semen must past the small vaginal orifice of the queen and then must be forced into the lateral oviducts. Many times the oviducts already contain semen from previous matings. Thus, the ejaculation of semen under great force is especially important during multiple matings.

During eversion of the endophallus, the mating sign is created without damaging the endophallus (Woyke, 1958b and Woyke and Ruttner, 1958). I suggest that during natural mating, the complete eversion of the endophallus separates the drone from the queen, after the mating sign is pushed into the sting chamber of the queen.

Partial evertion of the endophallus, with a slender tip at the end occurs also in Apis cerana (Woyke et al., 1973) and in Apis dorsata (Woyke, 2001 and Woyke et al., 2001). I suggest that the reason for this phenomenon is the same as in Apis mellifera.

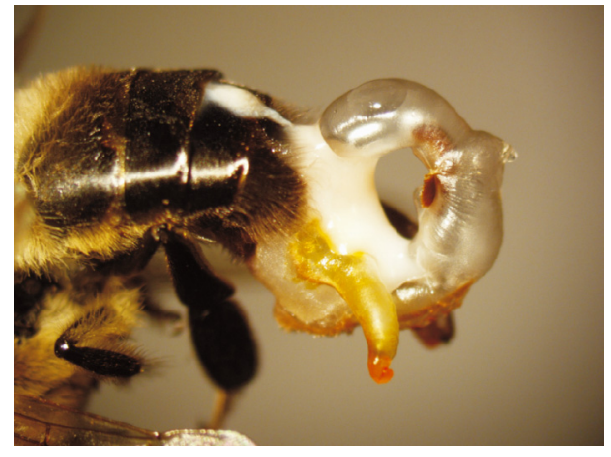

Figure 26. Fully everted endophallus, semen at the thorax.

Pourquoi l'éversion de l'endophallus du mâle d'abeille s'arrête-t-elle à mi-chemin et quelle en est la signification?

Apis mellifera / organe reproducteur / mâle / endophallus / éversion

Zusammenfassung - Warum stoppt bei Drohnen die Ausstülpung des Endophallus auf halbem Weg und welche Bedeutung hat dies? Zum Zweck der instrumentellen Besamung wird weltweit jährlich von etwa 800000 Drohnen Samen entnommen. Technisch gewinnt man Samen am einfachsten vom Ende des halb ausgestülpten Endophallus. Es ist jedoch völlig unklar, warum bei erregten Drohnen der Endophallus nicht bis zur vollen Länge ausgestülpt wird, sondern bereits auf halben Weg innehält. Wir untersuchten dies in der vorliegenden Studie. Reife Drohnen wurden getötet und seziert. Die Ergebnisse zeigen, dass die Querfalten an der ventralen Grenze des nichtausgestülpten Cervix (Abb. 8) einen Gang, den Cervicalductus, bilden (Abb. 9). Im Querschnitt laufen die dorsalen Wände in einem so spitzen Winkel zusammen, dass sie eng zusammengedrückt erscheinen (Abb. 10). Die Trennung der dorsalen Wände erfordert hohen Kraftaufwand. Abbildung 13 zeigt die Situation nachdem die dorsalen Wände auseinandergefaltet wurden. Zwei längsverlaufende Haarbänder sind auf beiden Seiten des Gangs zu finden. Innerhalb des Ductus verbinden sie sich mit den Seitenwänden und verengen sie, so dass sie nur schwer zu trennen sind. Während der teilweise Ausstülpung wird am Ende des Endophallus der Cervicalductus zwar sichtbar (Abb. 17), die dorsalen Wände öffnen (trennen) sich aber nicht. Der Durchmesser des teilweise ausgestülpten Cervicalductus beträgt nur $0,4-0,5 \mathrm{~mm}$. Abbildung 19 zeigt den teilweise evertierten Endophallus nach Entfernung der Seitenwände. Innerhalb des evertierten Teils des Endophallus 
ist der Rest des nichtausgestülpten Ductus zu sehen, sowie der Bulbus mit den Chitinplatten. Der Durchmesse des Bulbus beträgt etwa $2 \mathrm{~mm}$. Da ein solch grosser Bulbus nicht durch das dünne Ende des Ductus hindurch kann, bleibt die Ausstülpung auf halbem Wege stehen. Erst ein bedeutender Anstieg des Innendrucks innerhalb des evertierten Teils des Endophallus ist in der Lage die dorsalen Wände des Ductus auf besondere Art und Weise zu öffnen. Als erstes wird die hier beschriebene neue taschenförmige Struktur durch den Gang gedrückt, so dass eine transparente Blase am Ende des Endophallus sichtbar wird (Abb. 20). Die Tasche öffnet die Dorsalwand des Cervicalductus und erweitert dadurch den gesamten Innendurchmesser des Cervix. Nachdem der Bulbus in den evertierten Cervix gedrückt wurde, wird der Samen ejakuliert (Abb. 23). Dies ist das beste Stadium für die Samengewinnung zur instrumentellen Besamung. Ein weiterer (auf künstlichem oder natürlichem Weg herbeigeführter) Druckanstieg resultiert in der vollständige Ausstülpung des Endophallus (Abb. 25). Der kraftvolle Ausstoss des Samens ist von grosser Bedeutung, da er in die lateralen Ovidukte der Königin injiziert werden muss, die bereits Samen aus vorhergehenden Paarungen enthalten können.

\section{Ausstülpung / Endophallus / Apis mellifera / Re- produktionsorgane / Drohn}

\section{REFERENCES}

Arnhart L. (1936) Der ausgestülpte Penis der Drohne von Apis mellifica L., Arch. Bienenkd. 17, 63-71.

Arnhart L. (1937) Der unausestülpte Penis der Drohne von Apis mellifica L., Arch. Bienenkd. 18, 1-23.

Bishop G.P. (1920) Fertilization in the honey-bee, J. Exp. Zool. 31, 225-265.

Fyg W. (1952) The process of natural mating in the honeybee, Bee World 33, 129-139.

Huber F. (1792) Nouvelles observations sur les Abeilles, Barde, Manget. Genève.

Koeniger G. (1984) Funktionsmorphologische Befunde bei der Kopulation der Honigbiene (Apis mellifera L.), Apidologie 15, 189-203.

Laidlaw H.H. Jr. (1944) Artificial insemination of the queen bee (Apis mellifera L.), J. Morphol. 74, 429-465.

Leuckart R. (1873) Geschlechtlichkeit der dreierlei Bienenwesen, in: Berlepsch A. (Ed.), Die
Biene und ihre Zucht mit beweglichen Waben in Gegenden ohne Spätsommertracht, 3rd ed., Ernst Buchhandl. Quedlingburg und Leipzig, pp. 12-32.

Michaelis G. (1900) Bau und Entwicklung des männlichen Begattungsapparates der Honigbiene, Z. Wiss. Zool. 67, 439-446.

Ruttner F. (1968) L'organe génital mâle et l'accouplement, in: Chauvin (Ed.), Traité de biologie de l'abeille, Masson et Cie, Paris, pp. $145-185$.

Snodgrass R.E. (1956) Anatomy of the honey bee, Comstock Publ. Assoc. Ithaca, New York, 2nd ed.

Swammerdam J. (1738) Bybel der nature, Hermann Boerhaave, Leyden.

Wolf O.J. (1876) Ueber den Begattungsact der Biene, Bienenzeitung (Eichstädt) 32, 201-205 + 1 Pl.

Woyke J. (1955) Multiple mating of the honey bee queen (Apis mellifera L.) in one nuptial flight, Bull. Acad. Pol. Sci., Cl. II 3, 175-180 [available online] http://jerzy_woyke.users.sggw. pl/multmat.pdf (accessed on 3rd July 2008).

Woyke J. (1958a) Histologiczna budowa organów rozrodczych trutnia, Pozn. Tow. Przyj. Nauk., Wydz. Mat.-Przyr. Prace Kom. Biol. 19, 1-51 [Summary; Histological structure of drone reproductive organs. Poznań Soc. Friends Sci. Dept. Mathem. \& Nat. Sci., Publ. Sect. Agric \& Sylvicult.19, 36-38, 41-50 [available online] http://jerzy_woyke.users.sggw.pl/histdron.pdf (accessed on 3rd July 2008)].

Woyke J. (1958b) The process of mating in the honey bee, Pszcz. Zesz. Nauk. 2, 1-42 (in Polish, English summary: 40-42).

Woyke J. (2001) Eversion of endophallus and the probable mating process in Apis dorsata, Proc. VII IBRA Conf. on Tropical Bees and V Asian Apic. Assoc. Conf., Chiang Mai, 19-25 March 2000, 189-194 [available online] http://jerzy_ woyke.users.sggw.pl/doeverchm.pdf (accessed on 3rd July 2008).

Woyke J., Ruttner F. (1958) An anatomical study of the mating process in the honey bee, Bee World $39,3-18$

Woyke J., Ruttner F., Koeniger N. (1973) Reproduction in Apis cerana 2. Reproductive organs and natural insemination, J. Apic. Res. 12, 21-34.

Woyke J., Wilde J., Wilde M. (2001) Apis dorsata drone flights, collection of semen from everted endophalli and instrumental insemination of queens, Apidologie 32, 407-416.

Zander E. (1922) Der Bau der Biene, Eugen Ulmer, Stuttgart. 